Beyond Philology No. 16/2, 2019

ISSN 1732-1220, eISSN 2451-1498

https://doi.org/10.26881/bp.2019.2.08

\title{
Lacking limit: \\ Desire and the absurd
}

\author{
XYMENA SYNAK
}

Received 20.01.2018,

received in revised form 12.04.2019,

accepted 22.08.2019.

\begin{abstract}
The article attempts to analyze the existential idea of the innate conflict between me, a human being, and the world, set in the psychoanalytical context of the primary separation between me a tragic emptiness - and the other who is introduced to me in the form of the $\mathrm{m}(\mathrm{O})$ ther's womb. $(\mathrm{O})$ - from the French l'autre (the other) - literally marks the object-cause of my desire, l'objet a that escapes me radically (Latin radix meaning root), at the moment of me being born and separated from the mother. In this context, the radical separation made present in the primordial cut of the $(\mathrm{O})$ is the very secret of both death and language.
\end{abstract}

\section{Keywords}

sense, desire, trauma, eroticism

\section{Brakująca granica: pragnienie i absurd}

\section{Abstrakt}

Celem artykułu jest analiza egzystencjalnej idei konfliktu pomiędzy człowiekiem i światem, a umieszczonej w psychoanalitycznym (Laca- 
nowskim) kontekście pierwotnej separacji pomiędzy mna - tragiczna pustką - a innym, obecnym dla mnie w formie matczynego ( $m(O)$ ther's) łona. (O) $-\mathrm{z}$ francuskiego, l'autre (inny) $-\mathrm{w}$ sposób dosłowny zaznacza przedmiot-przyczynę mojego pragnienia przedmiot małe $a$ - który ucieka mi radykalnie (od łacińskiego radix, korzeń), w momencie moich narodzin i mojego oddzielenia od matki. $\mathrm{W}$ tym ujęciu, radykalna separacja uobecniona w pierwotnym cięciu (O) stanowi tajemnicę zarówno śmierci, jak i języka.

\section{Słowa kluczowe}

dotyk/sens, pragnienie, trauma, erotyzm

beauty is nothing but the beginning of terror

which we are barely able to endure, and it amazes us so, because it serenely disdains to destroy us.

Every angel is terrible.

R. M. Rilke, Duino Elegies

If we accept the fundamental existential idea that the absurd is, first of all, a dissonance within the coexistence of the human subject and the world, we have to make a reservation that it is a dissonance in the sense of life radically rooted in death, both (life and death) escaping the human subject's selfhood. While life and death intertwine, or rather hollow each other out, they turn the being into a space of radical disjunction, which results in the paradox of what may be called a "radical separation". It is a separation from the object-cause of my desire, the very separation becoming the strength of my desire; a resistance against the victory of the signifiant, the victory being a failure within the "absurdist logic" of desire.

Within this absurdist logic, the emptiness of sense, or of the symbolic, presents itself through the emptiness of the primordial cut within the $\mathrm{m}(\mathrm{O})$ ther's womb; of the incision that gives birth to the absurdity of existence. At this point one can risk the statement that the dissonance of the relation between me 
and the world to a great extent overlaps with the Lacanian notion of the real "in the form of" the emptiness of an imaginary object, the object itself being the object-cause of desire, yet escaping me radically (at the illusive core of my existence). What remains is emptiness described as a Thing (that terrifies), which means - following Lacan - that the emptiness (void) represented in the representation (the primordial cut of the maternal womb described by Lacan as l'objet $a$ or objectcause of desire) is in itself nothing. What is more, this - let us say - radical representation remains impossible without some tremble, or tension, at the very limit of its being born, namely, on the $\mathrm{m}(\mathrm{O})$ ther's skin.

Revealed at the moment of my birth, the Thing that terrifies belongs to beauty as "the beginning of terror" as well as to what Breton names "veiled eroticism" (Manifesto of Surrealism) or explosiveness of terror. Although veiled, eroticism reveals itself at the very limit where death and life converge. In this context, we can say that Camus' absurd is the terror of truth; truth devoid of meaning but carrying an intimate sense, as it touches me and permeates my interiority, radically and materially. In a psychoanalytical vein, absurdist truth hinges on the Lacanian notion of truth that proceeds only from what has no meaning, from a non-sense, or from what Žizek calls "the signifier of pure difference" (2016: 43). Would it be the truth of the maternal cut, or the split within the womb of the $\mathrm{m}(\mathrm{O})$ ther? The place of the Lacanian primordial object-cause of desire l'objet petit $a$ - materializes the non-being of desire, and, at the same time, names the nothing, the very lack of meaning, or, in other words, the metonymic space of desire itself: passing through the incision of the womb and the split within the symbolic of the $\mathrm{m}(\mathrm{O})$ ther, the split functioning as a rupture within the symbolic order, deprived of meaning. This significant void of meaning marks here the sense [from tenir to touch]: the lack falling off from the symbolic.

Being split, the maternal womb is set in tension: stained with the deciduous object-cause of desire, the primordial space of sense becomes the space of a traumatic event of me being 
born into the void. As l'objet petit a inscribes itself on this cutting line crossing the womb of the $\mathrm{m}(\mathrm{O})$ ther, it belongs to the unnameable truth of desire, which - absurdist in being deathdriven and in its relation to the lack - is the root of terror. "The object is something from which the subject, in order to constitute itself, has separated itself as an organ. This serves as a symbol of the lack, that is to say, of the phallus, not as such, but as far as it is lacking. It must, therefore, be an object that is, firstly, separable, and, secondly, that has some relation to the lack" (Lacan 1998: 103).

Related to the lack and identified with "libidinal negativities (l'objet petit $a$, jouissance, and sexual difference, $[\ldots]$ ), material meaninglessness both linguistic and non-linguistic, contingent traumatic events, unbearable bodily intensities, anxiety, and death" (Johnston), the emptiness of desire turns into the absurd of the unconscious; an absurd which is Camus' absurd a rebours - an absurd of the limit, or, of the split within the $\mathrm{m}(\mathrm{O})$ ther's womb. The absurd à rebours taking place at the moment of the primordial cut within the maternal womb, whether referring to thwarting the symbolic from within by the emptiness of the real or to the perceived lack within ungraspable otherness, or to the otherness as defining the ungraspable real/void, seems to be marked by a failure of representation, where the dissonance between me and the world can only be seen through the rhetoric of discontinuity that "subverts, or at the very least, contradicts the logical continuity of the grammatical model" (Felman 2003: 123).

Torn, on the one hand, by a desire for grammar, and, on the other, by a desire for rhetoric, psychoanalytical discourse struggles with its double, contradictory desire. In this perspective, the cut of the $\mathrm{m}(\mathrm{O})$ ther's womb instantaneously becomes discontinuous and figurative: as a figure of the objectcause of desire (l'objet petit a) and as a representation of the object lost or, rather, never possessed, the cut reveals the unpenetrable real. In existentialist terms, the cut/gap represents the unpresentable dissonance/discontinuity be-tween the human subject and the world; a dissonance thwarted from within 
by the logic of continuity where the desire to speak takes over and substitutes the place of the lack.

If everything that counts takes place within a rupture, to live means to live against the impossible, which in this case undergoes subversion and becomes the attempt to live the very impossible, on the brink of exhaustion. To think within the rupture, at the same instance, is to subvert the very rhetoric of the discontinuous so that it presents itself to the consciousness. Thus, living and thinking are, paradoxically, found meaningless, in the real, as something limiting and not affected by the way I think about it, with the real consisting in a hole as a lacking or disrupting element inherent in any representation. This results in a lack whose truth is a lacking meaning; truth that terrifies and manifests itself inscribed on the body of the $\mathrm{m}(\mathrm{O})$ ther: on the body both of the symbolic and of the primordial space of desire. In a continual displacement, metonymy/desire defines l'objet petit a: an object-cause of desire, an object from which the subject separates in order to constitute itself - as well as revealing the impossibility of truth; truth as the impossible - as the real: "Stumbling, faltering, splitting. In a spoken or written sentence something slips [...] It's there that something else is asking to be realized - something which appears as intentional, of course, but partaking of a strange temporality" (Lacan, 1998: 128). This absence of the presence of meaning is the very sense of the rhetorical model of the most intimate discontinuity; of the womb's cut as its symbolic and material (the real) manifestation, where to manifest means (sic!) to expose itself to the view without presenting itself. What exposes itself is the nothing of desire, i.e. the limit, or the absurdist shattered passage between me and the world. As the most intimate of cuts, the primary incision is a condition of possibility for any sense to appear, as well as for the absurdist sense of the trauma of birth to enter any signification, devoid, however, of the non-absurdist (grammatical) logic of continuity.

The trauma of birth entering signification opens up the possibility of "the conflict between desire and representation": "the 
essential drama of man having come to objective knowledge" (Alquie 1965: 159). The very conflict can only be represented à rebours, only through partial, oblique naked-ness, devoid of the immediacy of touch, whereas "[t]he body conditions everything that the imaginary register acco-mmodates by way of the signified, meaning and signification, and the image of the world itself. It is within the imaginary body that the words of a language bring in representations, which constitute an illusory world for us on the model of the body's unity" (Alain Miller 2014).

The illusion of unity creates a discourse of absence and of separation; a discourse in which the impossible loss defines the absurd of the erotic relation, or the erotic veiled experience of nakedness - of the absurdist mis-encounter between the body and the world. Defined by means of violence and pleasure, eroticism conceals the intense, innermost fear of touching the moment of abhorred nakedness; a nakedness through which the division between interiority and exteriority is drawn. Moreover, eroticism, as the pleasure and violence of a relation, is the very act of passage, of transformation, transitivity, and modalization. As a failure or a split, the subject of the relation becomes an acting force, doomed to missing the encounter with itself as well as with the outside. Although desire extends the gap within the subject, this suspension - the tension of the line of the primordial cut - constitutes the moment of the subject encountering its own lack, without which there cannot be any touch. Never overcome, the tension undergoes a weakening and an illusive disappearance, inseparable from an opening of the relation within the $\mathrm{m}(\mathrm{O})$ ther's body, where my pleasure relates me in myself to a subject that "I" am not, which is prior to and beyond me, to my desire and my pulsion, the rhythm of my breath. The rhythm is difference, the impossible line of appearance thanks to which desire as the relation within its-self is transformed into a painful pleasure of disappearance as becoming: 
[...] this pleasure is always a new version of the relation of the thing to its own appearance and disappearance. In effect, whether this "thing" consists in the representation of an object or a body from the perceived world, or whether it remains in a form without reference, what matters in it is the movement that detaches it from the formless in whose ground nothing is distinguished [...] The place that is estranged from all forms - a place, therefore, that is itself outside all place, a place without localization or consistence - is indicated in a special manner by two representations that act as representations of the unrepresentable - that of death, and that of sex [my emphasis]. These are not allegorical representations of the abstractions "death" and "sex" but representations of a dead person - a cadaver - and of organs of sexual reproduction. It is not by chance that these two kinds of representation are found posited at the beginning and end of the history of mimesis - Aristotle at the beginning, Freud at the end. (Nancy 2013b: 73-74)

Are not, however, first of all, death and Eros two moments (moments and not events, as they happen unnoticeably, within a blink of an eye) of the same, namely, of the impossible encounter with the trauma of birth? Are they not the very moment of convulsion where Bretonian convulsive beauty is born, veiled and contorted? In a continual, final (dis)(e)rup-tion? Disrupted at the very moment of drawing the line of the primordial cut that gives birth to the sense and the lost object-cause of desire - in the form of the abject (wound, blood, leftovers of flesh, spasmic cry) - the representations of death and sex are two sides of the veil. They both are present "in a disappearance of forms" (Nancy 2013b: 74), they make the incision within the $\mathrm{m}(\mathrm{O})$ ther's body possible: the formative cut "tames the formless" (Nancy 2013b: 75), thus giving birth to the world (l'origine $d u$ monde) and touching its own limit (Nancy 2013b: 75). The "fever of drawing" (Nancy 2013b: 78) pushing form to the limit turns into desire in the form of violence and pleasure, in a prayer exhaled through the lips of the $\mathrm{m}(\mathrm{O})$ ther's body; through the oracle of Eros and death. 
To draw a line - continues Nancy - is not to make a mark - as we know, it is "to follow one's desire," and in order to do this, to feel desire announcing itself, taking shape, complicating itself, dividing itself, and so on. [...] pleasure (which desires itself) encounters the impossibility of fulfillment (in other words, of pleasing itself) without itself being affected by excess or lack". (Nancy 2013b: 84-85)

The erosion of fulfillment - the subject's beginning with the primordial cut announcing death - inevitably leads to erasing the erotic veil: erasing as the unveiling of nakedness on the verge of death, or, rather, as the limit of touch [sense] being born. Yet, the cut does not mean death but announces it in the sense of self-distancing, in its "formless or the beyond-form of the origin-end" (Nancy 2013b: 78). Drawing the line, or following the desire of the self, of the very differentiation and not identity, brings it close to the Lacanian misencounter within the symbolic, within the $\mathrm{m}(\mathrm{O})$ ther's womb, and within the real trauma of birth itself:

[...] birth itself? Is it itself? Can it merely be, can it be something like "itself"? (Nothing more than a sister to death.)

How then could "something" be the very thing that precedes and prepares the presence of something in general? It would have to be something that, as a result, can have no presence itself. Or could birth itself be something not born, the only thing that is not born but that is simply there, without remainder, without becoming, nothing more than that? It would be being itself, nothing but birth as it is, un-born in some way and so never born and never to be born. But this being cannot be identified with birth in any way. Birth is the figure that is opposite of being, and thus neither nonbeing nor becoming. Becoming is continuous passage and alteration. But birth is the coming that has not yet become. It precedes this passage and only opens the way for it. It is not the origin; it is not engenderment. (Nancy 2013b: 30)

Dehiscence of the line of the primordial cut, of the line of the letter of abjection - petit $a$ - extends itself in the very act of exposing its mark, representation, its erotic and abhorred 
form: of the sexual organs as well as of the dead body. The opening is seizure; it is nothing, or the no of the thing, as it demonstrates itself in the distancing from its own self and passing through the void of reference. That nothing enters form (separation, division, opening) is - as Nancy defines it "reality of displacement by which that displaces itself and that distinguishes itself' (Nancy 2013b: 95; original emphasis). The line (of desire) is desire itself, paradoxically, unveiling the pure nakedness of form at the moment it (mis)encounters the real: the truth of the primordial cry.

What is left is the image of the real: the skin, bare and exposed, the place where the truth of the cry conceals itself; "[t]he secret is on the skin (the secret and the sacred)" (Nancy 2014: $3)$, the skin being the space of intrauterine life, "soft, immovable, warm, symmetrical, double and viscous" ((Nancy 2014: 3), or rather the very veil of the primordial exposition of erotiquevoilee (Breton). The veil of primordial exposition, the image of the real unveils the desire to take part in my own death, in the encounter with the primordial subject of the demand: "the Mother as Other [Autre]" (Lacan 1982: 12). However, satisfying no lack, but functioning in its excessive relation to the subject being born out of this relation, the object-cause of desire l'objet petit $a$ - "takes the place [...] of what the subject is symbolically - deprived of" (Lacan 1982: 15). Symbolic deprivation is always a deprivation à rebours, belated, and present in the shape of the $\mathrm{m}(\mathrm{O})$ ther's womb and the primordial cry. As the object $a$ takes place of what remains veiled, it is eroticism itself that "initially" partakes of death, where the object $a$ becomes the very object of abjection: the nothing of desire, the corpse, life's leftovers; the emptiness / hole through which the $\mathrm{m}(\mathrm{O})$ ther's body must pass in order to constitute itself as an object, naked and empty. Resulting from loss, the hole in the real initiates the movement of sense, or - to use Lacan's words - "sets the signifier in motion" (Lacan 1982: 38). Yet, sense here can only mean setting the signifier in motion if it is unveiled at the limit of touch, as touch exposes its limit. Hence, the line of the limit - the letter $a$ being inscribed as a mater- 
nal cut - is indissociable from the figure of death being born, namely of the secrecy of the letter, "the death's secret [which] is also the secret of language" (Das 2010: 17). In other words, death's intimacy which is also the intimacy of language, where "discourse cannot escape discourse" (Derrida in Abraham and Torok 1986: xxxii), coexists with the exposure of pure nakedness: the naked body unveils its edges, as if tracing the line of mournful desire; desire that can never be satiated. Mournful desire - a desire of the mournful, naked body - verges on the secret of language; a secret that comes to existence at the moment of the disclosure of desire: at the origin of the world, when the $\mathrm{m}(\mathrm{O})$ ther's thighs part and unveil death's secret: "a demand: call, incitation, excitation to go beyond utility and satisfaction in order to go toward the dismantling of self, abandon, to pass to the limit - a passage that does not clear a way but that brushes past, touching as it goes and in touching lets itself be touched by the outside (nothing-god)" (Nancy 2013a: 95).

Missed in the erotic experience, the nakedness of the encounter with the trauma of birth is eroticism-veiled: pure nakedness slits the border between the body and the world being born into indistinguishable moments of touch, i.e. the touching and being touched. Death's secret turns into death's shroud, which becomes the very name of language, the secret of which has been lost to the speaking lips. Eroticism-veiled unveils death's secret as the secret of language, but also as the secret of the lacking limit of desire: a lack of place where desire can be satisfied. Erotique-voilée thus provokes the very notion of relation that designates a thing:

If relation is pursued from the angle of a "something," we can say that there is no relation of the sexual, or that the sexual does not relate anything. Maybe this is what Lacan wants to indicate when he says that a relation writes itself and that the sexual does not write itself, by which we should understand that writing is a matter of consigning rather than signifying, a matter of a graph or algorithm rather than literature. Maybe the question is: What is there of the sexual relation in all of literature, poetry in particular 
(but perhaps also - who knows? - in all of philosophy)? (Nancy 2013a: 5)

There is no sexual relation makes there is the very space of relation that does not take (its) place; instead, that there is a relation makes the limit within the erotic misencounter with the trauma of birth possible. Blanchot's "essential solitude" (1989: 19-34) - absolute solitude: that there is absolute solitude establishes any possible relation, the erotic, convulsive relation turning out to be the primordial deferral of presence and all thought. That there is no relation is the differentiation that "shatters the one-in-itself" (Nancy 2013a: 10). This primordial separation - this cut, incision, the originating of the world establishes the very trauma of separation that takes its place on the $\mathrm{m}(\mathrm{O})$ ther's body, and takes on the form of a deciduous object of desire: the corpse, blood, excretions of the body, and, finally, of the fetus itself. Yet, taking its place is nothing more than missing the place, or cutting across it. This is the secret of death and of language; absolute intimacy spacing out in the impossible form of the erotic mis-encounter.

\section{References}

Abraham, Nicolas, Maria Torok (1986). The Wolf Man's Magic Word: A Cryptonymy. Minneapolis: University of Minnesota Press.

Alquie, Ferdinand (1969). The Philosophy of Surrealism. Ann Arbor: University of Michigan Press.

Blanchot, Maurice (1989). The Space of Literature. Lincoln, Nebraska: University of Nebraska Press.

Das, Saiyta Brata (2010). "(Dis)Figures of death". Derrida Today 3/1: 1-20.

Courbet, Gustave. L'origine du monde. 1866.

Felman, Shoshana (2003). Writing and Madness. Stanford: Stanford University Press.

Johnston, Adrian (2013, rev. 2018). Jacques Lacan. Stanford Encyclopedia of Philosophy. Available at <https://plato.stanford.edu/ entries/lacan/>. Accessed 27.06.2018. 
Lacan, Jacques (1982). "Desire and interpretation of desire in Hamlet. In: Shoshana Felman (ed.). Literature and Psychoanalysis: The Question of Reading: Otherwise. Baltimore: Johns Hopkins University Press, 11-52.

Lacan, Jacques (1998). Four Fundamental Concepts of Psychoanalysis. New York: W. W. Norton \& Company.

Miller, Jacques-Alain (2014). "The unconscious and the speaking body". Hurly-Burly 12/2015: 133-140.

Nancy, Jean-Luc (2013a). Corpus II: Writings on Sexuality. New York: Fordham University Press.

Nancy, Jean-Luc (2013b). The Pleasure in Drawing. New York: Fordham University Press.

Nancy, Jean-Luc (2014). Being Nude: The Skin of Images. New York: Fordham University Press.

Žižek, Slavoj (2016). Disparities. London: Bloomsbury Academic.

Xymena Synak

ORCID iD: 00 00-0002-6890-7181

Instytut Anglistyki i Amerykanistyki

Uniwersytet Gdański

Wita Stwosza 51

80-308 Gdańsk

Poland

xymena.synak@ug.edu.pl 